\title{
Historical Evidence and the Eastern Greenland Case
}

\author{
JANICE CAVELL ${ }^{1}$
}

(Received 20 November 2007; accepted in revised form 12 March 2008)

\begin{abstract}
The Eastern Greenland case (1931-33) is the only territorial dispute in the polar regions ever to have been decided by an international court. Norway challenged Denmark's claim to sovereignty over all of Greenland on the grounds that Denmark had established effective occupation in a limited area only. The Permanent Court of International Justice (PCIJ) held that effective occupation in the polar regions requires relatively little actual exercise of sovereign rights, and that Denmark therefore did indeed have sovereignty over the entire island. Both parties in the dispute based many of their arguments on historical evidence, most notably the records of a series of diplomatic overtures to other states made by Denmark between 1915 and 1921. These documents, the Norwegians argued, showed that the Danes themselves did not believe that they had sovereignty over the entire island. The Danes, on the other hand, contended that their sovereignty dated back to the Middle Ages. The Court found the Danish arguments more convincing. However, the dissenting opinion of Justice Dionisio Anzilotti upheld the Norwegian interpretation. This paper re-examines the issue in the light of historical evidence, found recently in Canadian archives, that was not available to the Court. These new documents indicate that Anzilotti's view was the correct one. While the 1933 decision in favour of Denmark can be upheld on other than historical grounds, a re-assessment of the historical evidence and arguments presented to the PCIJ is essential to set the record straight.
\end{abstract}

Key words: sovereignty, Eastern Greenland, polar regions

RÉSUMÉ. Le cas du Groenland oriental (1931-1933) constitue le seul conflit territorial des régions polaires à n'avoir jamais été tranché par un tribunal international. La Norvège avait contesté la revendication de souveraineté du Danemark sur tout le Groenland, sous prétexte que le Danemark n'avait effectivement occupé qu' une partie limitée de ce territoire. La Cour permanente de justice internationale (CPJI) a soutenu qu'une occupation effective des régions polaires ne nécessite qu'un exercice réel relativement faible des droits de souveraineté, et que par conséquent, le Danemark avait effectivement le droit de souveraineté sur toute l'île. Les deux parties visées par le conflit fondaient grand nombre de leurs arguments sur des preuves historiques, plus précisément les dossiers d'une série d'ouvertures diplomatiques faites par le Danemark à d'autres États entre 1915 et 1921 . Les Norvégiens soutenaient que ces documents prouvaient que les Danois mêmes ne croyaient pas avoir la souveraineté sur toute l'île. Pour leur part, les Danois affirmaient que leur souveraineté remontait au Moyen-Âge. La Cour avait trouvé les arguments des Danois plus probants. Toutefois, l'avis minoritaire du juge Dionisio Anzilotti venait appuyer l'interprétation des Norvégiens. Ce document examine cet enjeu de nouveau à la lumière de preuves historiques trouvées récemment dans les archives canadiennes, preuves qui n'étaient pas à la disposition de la Cour à ce moment-là. Ces nouveaux documents laissent croire que le point de vue du juge Anzilotti était exact. Bien que la décision de 1933 en faveur du Danemark puisse être maintenue en raison de motifs autres qu'historiques, la réévaluation des preuves historiques et des arguments présentés à la CPJI s'impose afin de tirer les choses au clair.

Mots clés : souveraineté, Groenland oriental, régions polaires

Traduit pour la revue Arctic par Nicole Giguère.

\section{INTRODUCTION}

The decision in the case of the Legal Status of Eastern Greenland, handed down by the Permanent Court of International Justice (PCIJ) in 1933, is frequently cited as an assertion of the principle that effective occupation in the polar regions requires relatively little actual exercise of sovereign rights (for example, see Shaw, 2003:437). The case was a ground-breaking one (Anon., 1933:151; von der Heydte, 1935:464). Since the 18th century, it has been a received principle in international law that settlement and extensive administrative acts by a state are required to establish its sovereignty over new lands. However, the PCIJ held that Denmark had sovereignty over all of Greenland even though Danish settlement and administration were confined to the southwestern coast of the island. The exacting requirements of international law were thus altered "to permit a flexible standard which depends upon the circumstances of the territory. The more isolated the territory and the fewer the inhabitants, the less stringent are the

\footnotetext{
${ }^{1}$ Historical Section, Foreign Affairs and International Trade Canada, 125 Sussex Drive, Ottawa, Ontario K1A 0G2, Canada; janice.cavell@international.gc.ca

(C) The Arctic Institute of North America
} 
requirements of effective occupation" (Triggs, 1986:30; see also Waldock, 1948; Rothwell, 1996). Indeed, it has even been said that "the doctrine of effective occupation barely exists in remote and sparsely occupied territories" like the Arctic and Antarctic (Triggs, 1986:31-32).

In the words of legal scholar Oscar Svarlien (1964:72), the Eastern Greenland case is still "of paramount importance as regards territorial claims in polar regions. It is the only case involving a territorial question in the Arctic to be decided by an international tribunal which...had the opportunity to lay down the relevant rules of law." Moreover, the principle enunciated by the PCIJ in this case has been applied to territorial disputes outside the polar regions. In recent cases decided by the International Court of Justice and at least one arbitral tribunal, the rule that occupation of remote, inhospitable, and thinly populated land may be effected by relatively little state activity has proved crucial, and in every instance it has been backed up by reference to a single case: Eastern Greenland (see Eritrea/ Yemen Case, 1999:118; ICJ, 2001:100, 2002:682).

Behind this apparently straightforward legal principle lies a historical chain of events which was anything but simple or easy to understand. The contention of this article is that the PCIJ chose to ignore many of the historical complexities of the case in order to render a decision that appeared just and equitable on other than historical grounds. Without questioning the validity of these other grounds, it is useful to re-examine the development of the dispute between Denmark and Norway and the historical arguments put forward by the two countries, and to consider the case in the light of historical evidence that was not available to the Court.

Between 1721 and 1921, Denmark established and administered colonies on the southwestern coast of Greenland. An outpost on the eastern coast was added in 1894, but vast areas in the eastern and northern parts of the island were outside Danish rule. Foreigners were barred from even entering the colonies except at certain ports or in cases of shipwreck, and after 1774, the state-owned Royal Greenland Company monopolized all trade in the colonized areas. In the north and the east, however, British, American, and Norwegian explorers, hunters, and whalers roamed freely from the middle of the 19th century on, and the British whalers and American explorers occasionally engaged in trade with the Inughuit of Thule in the northwestern part of the island. The Danish government made no attempt to regulate their activities (Vaughan, 1991; Svarlien, 1964).

Between 1915 and 1921, Denmark made a series of diplomatic overtures to other nations, with the aim of obtaining their consent to the extension of Danish authority over the entire island. The initial impetus for this series of events came from the United States. In October 1915, the American secretary of state, Robert Lansing, informed the Danish minister in Washington that his country wished to purchase the Danish West Indies. The purchase was a high priority for the Americans, who feared a German invasion of Denmark and subsequent German use of the Danish islands as a naval base. In December 1915, the Danes put forward the suggestion that, in addition to making a cash payment for the islands, the Americans should declare that they would not contest the extension of Danish sovereignty over all of Greenland (U.S. Department of State, 1940:501-511; Tansill, 1966). The agreement, signed on 4 August 1916, included the statement that the government of the United States would "not object to the Danish Government extending their political and economic interests to the whole of Greenland" (U.S. Department of State, 1971:62).

After the end of the First World War, Denmark raised the Greenland issue with the other powers. On 14 July 1919, the Danish minister in Oslo informed the Norwegian government of Denmark's plans; in response, Norwegian foreign minister Nils Ihlen stated on 22 July that his government "ne ferait pas de difficultés au règlement de cette affaire" (PCIJ, 1933d:2553). Diplomatic notes were addressed to Great Britain (16 March 1920), Italy (17 March 1920), France (20 March 1920), and Japan (12 May 1920). The French, Italians, and Japanese all made favourable replies in March-June 1920. The British, however, demurred. In a note dated 20 July 1920, the Danes insisted that their sovereignty over the entire island was of long standing, dating back to the settlement founded by Hans Egede in 1721. On 6 September 1920, the British acknowledged Danish sovereignty, but they reserved the right to be consulted should the Danes ever decide to sell the island (PCIJ, 1933c:1824-1832; 1933b:45-48).

In January 1921, the Danish government asked the Norwegians for a written confirmation of Ihlen's verbal promise. When there was no reply, the Danes repeated the request on 29 April 1921. Again, there was no reply. On 10 May 1921, Denmark formally declared its sovereignty over all of Greenland, at the same time extending the Royal Greenland Company's trade monopoly. The Norwegians promptly registered their dissent. Eastern Greenland, they insisted, remained a terra nullius or no man's land, where they were free to operate as they wished. A Danish note dated 19 December 1921 informed the Norwegians that Denmark's sovereignty over all of Greenland was of long standing (PCIJ, 1933c:1580 - 1592). A compromise agreement whereby Norwegian hunters and whalers could continue their economic activities on the eastern coast ultimately failed. In June 1931, a group of Norwegians raised their national flag at Mackenzie Bay, and on 10 July, a royal proclamation formally claimed the eastern coast between $71^{\circ} 30^{\prime} \mathrm{N}$ and $75^{\circ} 40^{\prime} \mathrm{N}$, giving it the name Eirik Raudes Land. Denmark immediately took the case to the PCIJ (Svarlien, 1964).

The Court held in its decision of 5 April 1933 that Denmark had long since established sovereignty over the entire island, not merely the colonies, and that Norway was estopped from laying claim to any part of Greenland by its acceptance of the Treaty of Kiel (1814), by a number of commercial treaties that named Greenland as a Danish 
possession, and by the Ihlen declaration (as it became known). Norway's contention that Ihlen did not have the authority to give such an undertaking without the consent of the Norwegian storting (parliament) was rejected. The Court also rejected Norway's argument that "the attitude which Denmark adopted between 1915 and 1921, when she addressed herself to various Powers in order to obtain a recognition of her position in Greenland, was inconsistent with a claim to be already in possession of the sovereignty over all Greenland, and that in the circumstances she is now estopped from alleging a long established sovereignty over the whole country" (PCIJ, 1933c:45). The Norwegian occupation was therefore deemed unlawful.

In many ways, the decision in Denmark's favour was unquestionably the right one: between 1915 and 1921, Denmark had shown the intention to act as sovereign over the entire island, and several nations, including Great Britain and the United States, had given their consent to the extension of Danish rule, as had Norway with the Ihlen declaration. Between 1921 and 1931, the Danes substantially increased their activities in the east and the north. By the critical date of 1931, therefore, Denmark's sovereignty over all of Greenland had been established, even though its administration had not yet been extended to every part of the island (see the decision in the Clipperton Island Case, 1932).

However, a careful examination of the record shows that the historical evidence submitted by Denmark was far from sufficient to prove that its sovereignty over the uncolonized areas long predated the dispute with Norway. The Court's use of the historical data available to it was often questionable and always highly unsystematic. In contrast, the painstaking analysis of the historical record in the dissenting opinion of Justice Dionisio Anzilotti is a model of lucid thinking (on Anzilotti, see Ruda, 1992). Anzilotti agreed that Norway was bound by the Ihlen declaration. However, he was not convinced that Danish actions before 1921 were sufficient evidence of an intention to act as sovereign. Instead, he concluded that Denmark's diplomatic overtures to other nations in the early 20th century were undertaken precisely because the Danes themselves did not then believe that they had sovereignty over the entire island. Justices Schücking and Wang, though they concurred in the Court's decision, agreed with Anzilotti that between 1915 and 1921, "Denmark herself did not maintain towards the other interested Powers the theory of an already existing Danish sovereignty over the whole country" (PCIJ, 1933a:96).

Evidence that was not available in 1931-33, but which has recently come to light among the papers of Canadian geographer and Arctic expert Trevor Lloyd, demonstrates conclusively that, as Anzilotti, Schücking, and Wang realized, the Danish government did not believe that it had title to the entire island prior to 1921. During the late 1960s and early 1970s, Lloyd made an extensive collection of Danish documents, now held by the Trent University Archives, about the history of northern Greenland. A 1925 letter from Knud Rasmussen to O.D. Skelton at Library and Archives Canada provides important additional evidence. These documents show that by 1910, when Rasmussen founded his trading station at Thule, the Danes wished to extend their rule over all of Greenland. However, they feared opposition from the Americans or the British, since both of these nations could have put forward a claim to northern Greenland. Danish diplomatic manoeuvres therefore contained a strong element of bluff. The same tactics that had produced the acquiescence of the British in 1920 were successfully employed against the Norwegians in $1931-33$.

This article compares the Court's use of the available historical evidence on Eastern Greenland with Anzilotti's exemplary analysis of the same facts, and it will demonstrate the validity of Anzilotti's reasoning by reference to the previously unpublished historical documents on the history of the Thule station. Correct though the broad conclusions drawn by the Court may have been, Anzilotti's arguments are still of great interest and value, illustrating as they do a high level of rigour and sophistication in the evaluation of historical data.

\section{THE HISTORICAL ARGUMENTS PRESENTED TO THE COURT}

Rather ironically, the Greenland colonies came to Denmark by way of Norway. The two original colonies, Estribygd (the East Settlement) and Vestribygd (the West Settlement), were founded by Eirik Raude in the 10th century, and at first were independent. They became formally subject to Norway in 1261. Sturla Thórdarson's Hákonarsaga provides the only surviving account of the agreement between the Norwegian king and the colonists. The saga relates that the king sent emissaries to Greenland; on their return, the emissaries reported that the settlers were willing to pay tribute to Norway, and that they would also pay fines for all killings of either settlers or native Greenlanders, whether these took place in the settlements or on journeys to the north, "right up to the Pole Star" (Gad, 1971:120). The West Settlement died out in the 14th century, possibly as a result of conflicts with the native Greenlanders (Gad, 1971). In 1380, Norway and Denmark were united under one crown, and by the early 16th century, Norway had been reduced to the status of a Danish province. Contact between Denmark-Norway and the East Settlement was lost early in the 15 th century because of worsening climatic conditions and heavy ice along the coast. This settlement too died out sometime in the next century and a half (Gad, 1971). Until the early 19th century, all attempts to approach the eastern coast of Greenland were thwarted by ice.

Scandinavian settlement on Greenland was revived by the Norwegian missionary Hans Egede in 1721. With the permission of the Danish government, Egede founded a trading station and Lutheran mission at Godthåb (present- 
day Nuuk). Subsequently, Danish-Norwegian trade was carried out by several different companies, each in turn granted a monopoly by the government. These companies had difficulty in making a profit because of intense competition from Dutch traders. In response, the Danish government issued a series of proclamations banning foreign trading in or near the Danish settlements. Despite the occasional use of naval vessels and armed merchantmen to protect Danish interests from 1736 onward, the Dutch continued their activities. In response, the number of Danish colonies was steadily increased, and by the 1770s, the area of colonization extended as far north as Upernavik. In 1774, the Danish government granted the monopoly of trade to the state-owned Royal Greenland Company, and in 1776, the most detailed in the series of royal proclamations was issued, declaring the coast of Greenland from Julianehåb to Upernavik closed to foreigners (and also to the majority of Danes) (Gad, 1973). The various 18thcentury proclamations and ordinances asserted the rights of the kings of Denmark-Norway as "Souverains Seigneurs et héréditaires du Groenland et des îles en dependant" (PCIJ, 1933c:1534). The settled areas were referred to as "les Colonies par Nous établies dans Notre pays de Groenland" (PCIJ, 1933c:1531). Among these decrees was one that included an injunction against harming the native Greenlanders, even outside the colonies (PCIJ, 1933c:1533).

By the 1814 Treaty of Kiel, Norway was separated from Denmark and placed under the crown of Sweden. Denmark retained the Greenland colonies, along with Iceland and the Faroe Islands. The Norwegians, indignant both at being placed under Swedish rule without their consent and at the loss of their ancient colonies, initially rejected the treaty, but they were compelled to accept it in the Stockholm Convention of 1 September 1819 (Svarlien, 1964).

The dominance of Denmark over Norway in the period between 1380 and 1814 and the circumstances under which the Danes retained the former Norwegian possessions produced considerable animosity between the two countries, which lasted well into the 20th century. Perhaps because of this long-standing resentment, the Norwegians focused too intensely on historical grievances from the distant past when they brought their case before the Court (Berlin, 1932:25-36). The Norwegians made a number of accusations against the Danes: that they were responsible for the loss of contact with the East Settlement in the 15th century (thereby losing any rights derived from Norway's sovereignty over Greenland); that they had deliberately resorted to trickery during the negotiations leading up to the Treaty of Kiel; and that they had acted illegally in separating the Norwegian colonies from Norway (Svarlien, 1964:14-15). According to the Norwegians, Denmark-Norway had lost its former claims when the East Settlement was abandoned. Therefore, in the 18th century the Danish-Norwegian crown had sovereignty only over the colonized areas. The rest of the island was, and remained, a terra nullius.
Though the ordinances spoke of "Greenland" as a Danish possession, the term referred only to the colonies. Denmark retained this limited sovereignty through duplicitous means, and Norway did not consent to the transfer of the colonies to exclusive Danish ownership. The Norwegians insisted that because their storting had not ratified the Treaty of Kiel, its provisions were not binding on them (see Bull, 1929; Smedal, 1931; Skeie, 1932).

The Danes, in turn, argued that the old Norwegian monarchy had sovereignty over all of Greenland; that these rights were retained by the Danish-Norwegian crown after the union of 1380 and throughout the period when there was no contact with the East Settlement, to be asserted once again in the 18th century; and that full sovereignty over the entire island was lawfully retained by Denmark in 1814 (see Rasmussen, 1927, 1931; Berlin, 1932; Federspiel, 1932). The Danes were able to demolish many of the Norwegian claims. It was relatively easy to prove that the abandonment of the East Settlement occurred by force of circumstances, not intention; that Danish actions in 1814 were lawful; and that, however reluctantly the Norwegians had accepted the Treaty of Kiel, they had indeed accepted it. However, even if Denmark had lawfully retained the colonies, all the Danish arguments based on history were invalid if the Danes themselves did not believe before 1921 that they had sovereignty over the uncolonized areas. It was perhaps Norway's greatest mistake not to have focused more strongly on the years between 1915 and 1921. In choosing instead to air their many historical grievances on the subject of their lost colonies, the Norwegians at times appeared overly emotional and vindictive.

\section{THE COURT'S DECISION}

The Court began by observing that because the critical date was 10 July 1931, it was not "necessary that sovereignty over Greenland should have existed throughout the period during which the Danish Government maintains that it was in being." Nevertheless, it went on to fully uphold all of Denmark's historical claims. The Court concluded that in the 13th and 14th centuries, because fines were to be paid to the King of Norway for killings that took place outside the colonies, "[s]o far as it is possible to apply modern terminology" to the situation, Norwegian rights "amounted to sovereignty" and "were not limited" to the settlements. During the period between the loss of contact with the colonists and the resettlement of 1721, the claims of the Danish-Norwegian monarchy "amounted merely to pretensions," but in the absence of any claims by other nations, even pretensions carried some weight (PCIJ, 1933a:45-48).

As noted above, 18 th-century Danish ordinances spoke of "Greenland" as a Danish possession. In the Court's opinion, the burden of proof was on Norway to demonstrate that the word should not be considered as meaning 
the entire island, and Norway had not presented sufficient evidence to establish this. In addition, one decree had forbidden violence outside the colonized areas. Therefore, "bearing in mind the absence of any claim to sovereignty by another Power, and the Arctic and inaccessible character of the uncolonized parts of the country, the King of Denmark and Norway displayed during the period from the founding of the colonies by Hans Egede in 1721 up to 1814 his authority to an extent sufficient to give his country a valid claim to the sovereignty, and ... his rights over Greenland were not limited to the colonized area." Norway's acceptance of the Treaty of Kiel in 1819 must be regarded as an undertaking "not to dispute Danish sovereignty over Greenland." While the Ihlen declaration could not be interpreted as an acknowledgement of a pre-existing Danish sovereignty, it was "beyond all dispute" a binding promise not to contest or place difficulties in the way of Danish claims (PCIJ, 1933a:49-51, 64, 71).

As for the Danish diplomatic correspondence with other nations during the years 1915-21, it was certainly true that the expression "extension of sovereignty" was used, and that this expression, "if taken by itself," would be "very difficult to reconcile" with Danish claims to longstanding sovereignty over the entire island. However, the Court had decided that "too much importance must not be attached to particular expressions here and there." The different expressions used in the various notes were undoubtedly the result of the fact that they were not all drafted by the same individual. The Court was satisfied that the aim of the Danish government throughout the period in question was "to secure... an assurance from each of the foreign governments concerned that it accepted the Danish point of view that all Greenland was already subject to Danish sovereignty and was therefore content to see an extension of Denmark's activities to the uncolonized parts of Greenland." The Court conceded that "well-qualified private persons" in Denmark had expressed the opinion that in the absence of effective occupation on the east coast, the area remained a terra nullius. However, there was no evidence to show that the Danish government itself had ever held this view. According to the Court, the government made its overtures in order to have foreign states acknowledge Denmark's already existing sovereignty, so that any doubts there might be on this subject at home or abroad would be removed (PCIJ, 1933a:54-56).

In conclusion, the Court reiterated that even if the period from 1921 to 1931 was judged "by itself and without reference to the preceding periods," Denmark's actions in those years must be considered "sufficient to constitute a valid claim to sovereignty." When the historical background was taken into consideration, the finding in Denmark's favour was "confirmed and strengthened" (PCIJ, 1933a:63-64).

\section{ANZILOTTI'S OPINION}

Anzilotti opened with an expression of his fundamental disagreement with the way the Court had approached the case. In his mind, the key issue was the Ihlen declaration, and the Danish request to Norway in 1919 was "only one of several similar overtures on the part of the Danish Government addressed, from the end of 1915 onwards, to a number of States with a view to defining and securing its position in Greenland." Therefore, it was not possible "rightly to appreciate the request with which we are concerned unless we consider it in conjunction with the whole series of overtures of which it formed part" (PCIJ, 1933a:76-77).

The focal point of Anzilotti's analysis was therefore the diplomatic correspondence from the period 1915-21. He noted that the Danes "had every interest in presenting the request addressed to the Norwegian Government, and other similar overtures, in the light of a preconceived theory" (PCIJ, 1933a:76). Unlike his colleagues, who dismissed the expression "extension of sovereignty" as not characteristic of the correspondence as a whole, Anzilotti preferred to study the documents in chronological order, carefully noting variations in wording, and considering the possible reasons for any changes. In his view, the language used in the various replies was crucial, indicating as it did how the governments addressed understood the Danish request.

Anzilotti pointed out that the Danish request to the United States in December 1915 was of particular importance because it was the first in the series, and because "in all the overtures successively undertaken by it, the Danish Government expressly referred to the request made to the United States of America; the American declaration was submitted to the other governments as a model for the declaration asked of them" (PCIJ, 1933a:78). The Danes had clearly asked the Americans for an undertaking not to contest the extension of their sovereignty. Internal Danish documents from 1915 and 1916 also spoke of an extension, not a recognition, of sovereignty. It was therefore evident to Anzilotti that at this point, the Danes had not either believed or claimed that their sovereignty over the entire island pre-dated the correspondence. Nor could the American statement of 1916 be interpreted in any other way than as an agreement not to dispute the extension of Danish sovereignty.

Denmark's request to Norway in July 1919 and its notes to Britain, France, Italy, and Japan in March-May 1920 were all couched in similar terms. The Danes spoke of a preexisting sovereignty only to the British, and only in July 1920 - that is, after the British had proved reluctant to give the undertaking requested by Denmark. Accordingly, the French and Japanese replies agreed to an extension of sovereignty, while the Italian note stated that "the Royal Government will have no difficulty in recognizing the sovereignty of Denmark over Greenland." In other words, the Italians were willing to acknowledge Danish sovereignty 
at some point in the future, after it had been established. The British note of 6 September 1920, in contrast, seemed to recognize a pre-existing sovereignty, although the fact that the British reserved the right to be consulted in the event that the Danes ever sold Greenland raised some doubt as to whether this was in fact their intention (PCIJ, 1933a:81).

When the Norwegians protested against the Danish proclamation of 10 May 1921, they too were told (in December 1921) that Danish sovereignty was of long standing, and so did not now require recognition from other states. As Anzilotti shrewdly observed, "the Danish Government affirmed the pre-existence of its sovereignty over all Greenland when it was necessary to do this in order to refute claims which it was unable or unwilling to admit; apart from such cases, it confined itself to asking for a recognition of an extension of its sovereignty." The notes addressed to Great Britain in July 1920 and to Norway in December 1921 could not, then, be considered as representing the Danish government's true position; rather, they were part of a carefully calculated bluff. "[T]he only conclusion which I find it possible to derive," Anzilotti wrote, "is that...the Danish Government was perfectly aware of the possibility of adopting either attitude: viz. that of affirming an already existing sovereignty, and requesting its recognition, or that of urging reasons in support of an extension of its sovereignty, and requesting the recognition of this extension. It elected to adopt the latter attitude and resorted to the former in the course of a discussion and to avoid conditions or limitations which it felt unable to accept" (PCIJ, 1933a:80-81; for a similar conclusion, see Preuss, 1932:474).

As for the other historical evidence put forward by Denmark, in Anzilotti's opinion the payment of tribute and fines to the Norwegian king by the Greenland colonists was an acknowledgement of Norway's suzerainty, not its sovereignty in the modern sense. With regard to the 18th century, he noted the vast "disproportion between the claim to sovereignty over all Greenland and the effective exercise of that sovereignty." Anzilotti considered it an "essential point" that there was "a profound difference between the colonized regions of Greenland and the remainder thereof; for, whereas in the colonies there was a regular administration and a judicial organization, in the remainder of Greenland there were perhaps laws in force but no authority to enforce them: in fact-and this is a circumstance as exceptional as it is significant-no officials had even been appointed competent to decide disputes or to apply and ensure respect for the law." The requirements of international law might have been satisfied by this situation in earlier ages, but by the 18th century those requirements had changed, and Danish practices had not changed along with them. In the 18th and 19th centuries, grandiose but insubstantial territorial claims made by other nations had been either abandoned or made effective. Claims based on the old Norwegian rights were no longer relevant by 1721. At the time of the Danish re-colonization, Greenland was a terra nullius, and sovereignty over it had to be gained "in accordance with the rules governing occupation" (PCIJ, 1933a:83-84).

Anzilotti could easily understand why the Danish government felt anxiety about the parts of Greenland that had not been effectively occupied. It was certainly not in the government's interest to make any public acknowledgement of its concerns, and Anzilotti felt that no significance should be attached to the fact that it had not done so. That serious doubts had existed in Copenhagen was "proved by the very overtures which [Denmark] made. A proceeding of this kind is explicable only when the government which resorts to it thinks it necessary to safeguard a doubtful or unsettled position." As Anzilotti pointed out, action of this type had "not been often resorted to." That the Danes should ask other countries to consent to an extension of their sovereignty was "the clear and natural outcome" of the "historical development of Denmark's position in Greenland." Anzilotti concluded that, while the Ihlen declaration was indeed binding on Norway, and the Norwegian occupation was therefore unlawful, "[because] Denmark admitted to Norway in 1919 that there were parts of Greenland which were not yet subject to her sovereignty, she could not now adduce a sovereignty over the whole of Greenland, existing prior to that date" (PCIJ, 1933a:84-86, 94).

\section{NEW EVIDENCE}

An important question not asked by Anzilotti was why the Danes chose to request the agreement of other powers to the extension of their sovereignty rather than simply to go ahead with effective occupation. Indeed, it may have seemed to the other members of the Court that for Denmark to request the recognition of an already existing sovereignty over all of Greenland from other states was a reasonable way of proceeding, while there would have been less point in asking foreign governments to agree to a proposed extension of Danish sovereignty. If the Danes did not believe that their sovereignty extended beyond the colonies, but wished to bring the entire island under their rule, why not establish occupation, and then present the other powers with a fait accompli? There had been no other claims to Greenland in all the centuries since its discovery, so why should the Danes fear opposition? The government of Canada, which found itself in a similar situation with regard to Arctic sovereignty in the early 20th century, made no approaches to other countries before dispatching A.P. Low and Joseph Bernier on their northern voyages in 1903 and 1906, or before establishing Royal Canadian Mounted Police posts on several Arctic islands during the 1920s.

The answer to this question lies in the history of northern, not eastern, Greenland. Here the Danes might well anticipate claims from two of the great powers, Britain and the United States. In the United States, Arctic explorer Robert Peary was a vocal and potentially very influential advocate of an American territorial claim. 
Danish expeditions were sent to the eastern coast of the island in $1829-30,1883-85,1891-92,1898-1900$, and 1906 - 08, but before 1902, no Dane had even visited northern Greenland except as a member of a British or American expedition. British explorers John Ross (1818) and Edward Augustus Inglefield (1852) made the important early discoveries in the North. They were followed by Americans Elisha Kent Kane, Charles Francis Hall, Adolphus Greely, Robert Peary, and Donald MacMillan, and by another British expedition under Sir George Nares. Hall, as the leader of an officially sponsored expedition, raised the American flag and claimed the territory he had discovered for the United States on 5 September 1871 (Davis, 1876:104). From the 1880s until the beginning of the First World War, Scottish whalers regularly visited the Inughuit settlements on the Greenland side of Smith Sound. The first Danish expedition to northwestern Greenland was Ludvig Mylius-Erichsen's Danish Literary Expedition (1902-04). The Literary Expedition was privately sponsored, and its main objective was ethnographic work among the Inughuit. However, both Mylius-Erichsen and his companion Knud Rasmussen had definite political aims as well. They were anxious to secure northern Greenland for Denmark, and they hoped that their expedition would be the precursor of permanent Danish settlement (Vaughan, 1991; see also Lindow, 1929). In the early years of the 20th century, however, the region was almost the exclusive private preserve of the American, Peary. Peary wintered in the Smith Sound area in 1891-92, 1893-95, and 1898-1902. His first objective was the exploration of northern Greenland, which he completed in 1900. From 1900 to 1909 , Peary's goal was the attainment of the North Pole.

A man driven by relentless ambition, Peary reacted with intense hostility and competitiveness to intruders in "his" world. When Norwegian explorer Otto Sverdrup appeared in Smith Sound in 1898, Peary refused all friendly overtures from his rival, and set out in the dead of winter to establish a more northerly base. In the face of such steely determination, combined with unfavourable ice conditions in the area, Sverdrup abandoned his plans to take his ship up Nares Strait and to explore the northeastern coast of Greenland. Instead, he turned his course away from Peary's domain and explored to the west of Ellesmere Island (see Herbert, 1989). The presence of a rival, then, merely spurred Peary on to greater efforts. Peary had a firm economic and emotional hold over the Inughuit, whom he employed as hunters and dog drivers. During the periods when he was in the United States, they eagerly awaited his return, since they needed fresh supplies of necessities like ammunition and luxuries like biscuits. Even when they resented his commanding ways, it was hard for the Inughuit to deny his requests. "People were afraid of him... really afraid... You always had the feeling that if you didn't do what he wanted, he would condemn you to death," one Inughuk recalled decades later (Malaurie, 1982:121, 234). So long as Peary was a regular visitor to northern Greenland, there was no hope of establishing even an unofficial Danish presence there. Danish geographer H.P. Steensby (1909:892) sourly described him as the "uncrowned monarch, who considers himself the legitimate owner of all countries and inhabitants from Cape York and northwards." Perhaps significantly, the Danish Literary Expedition did its work during one of the intervals when Peary was not in the North.

In 1909, however, Peary at last reached the North Pole (or claimed to have done so), and he left the Arctic for good. At the same time, Rasmussen discovered that Sverdrup had plans to return to Smith Sound now that Peary had gone, and to establish a trading station there. He also heard rumours of German plans to trade with the Inughuit. Rasmussen therefore strongly urged the Danish government to take action. In March 1910, his proposal for a Danish station was discussed by a committee including officials from the Ministry of the Interior and from the Royal Greenland Company (Nyeboe, 1935). As Rasmussen himself recorded, he "received an answer to the effect that the land being considered No Man's Land, the Danish Government...did not see its way to establish a station there" for fear of provoking explicit American or British claims. Any Danish actions "would therefore have to be left to a private initiative" (Rasmussen, 1925). It was hinted to Rasmussen that though "foreign policy considerations prevented the government from proceeding...there might later be a possibility of a takeover, once everything had been put in place by private means" (Rasmussen, 1926; see also Sand, 1934; Gilberg, 1988:47). In other words, Rasmussen was to establish a Danish presence while leaving the government free to disavow any responsibility for his actions should Peary persuade the American government to protest.

Rasmussen accordingly acted on his own, hoping that the existence of a private Danish trading post would at least forestall claims by other governments. His task was made much harder by the fact that the cautious government, determined to avoid any difficulties with the Americans and British, flatly refused to provide a declaration that it had nothing against the plan. Without such a declaration, potential backers were wary. Rasmussen nevertheless finally obtained sufficient funds with the help of his friend, engineer Ib Nyeboe (Nyeboe, 1935). Accompanied by another young Dane with a taste for northern adventure, Peter Freuchen, Rasmussen returned to Greenland in the summer of 1910. The two men were determined "to finance our own [expeditions] by trading with the natives, furnishing them with goods, making a living for ourselves, and at the same time making the northern, as well as the southern, part of Greenland Danish territory" (Freuchen, 1935:35, 45). From their station, which they named Thule, Rasmussen and Freuchen carried out important explorations of the northern coastline and interior in 1912 and $1916-18$.

The documents on the history of Thule, then, record explicit statements by Danish government officials that they considered northern Greenland a no man's land. (Of 
course, these documents are only indirect records of the government's position, but given the strong patriotic feelings of Rasmussen and his associates, there is no reason to doubt the accuracy of their evidence.) The accounts written by Rasmussen and Nyeboe show that a cautious attitude prevailed in Copenhagen: officials there were determined not to risk any confrontation with the United States or Britain. As it turned out, the 1915-16 approach to the United States was successful despite Peary's strong opposition (see Anon., 1916a, b; Stafford, 1974; Stefansson, 1974a, b). Great Britain, in turn, proved to have no wish to press its claims beyond asserting a right to be consulted should the Danes ever sell Greenland. Denmark therefore had little to lose - and much to gain-by claiming to Norway in 1921 and to the Court in 1931-33 that Danish sovereignty over all of Greenland was of long standing.

\section{CONCLUSION}

The Court's decision to ignore the references to an extension of sovereignty in the diplomatic correspondence is, in itself, difficult to justify, especially in the light of the new historical evidence cited above. However, a narrowly historical focus would exclude many other relevant considerations. Undoubtedly, the Court upheld the Danish case because of Denmark's strong position at the critical date of 10 July 1931, and because the Ihlen declaration, as Anzilotti agreed, was a major stumbling block for the Norwegians. Moreover, a finding in favour of Norway would have opened up the possibility of disruptive claims and counter-claims about other sparsely populated territories in a world already containing more than enough potential for international conflict.

It would be highly unreasonable for international law to apply the criteria for effective occupation as stringently in the polar regions as it does in the temperate zones (see von der Heydte, 1935:462-471; McKitterick, 1939:93-94). When taken in a broad context, the Court's decision was the right one. Nevertheless, the historical evidence should now be evaluated more critically than the Court chose to do at the time. Anzilotti's careful, systematic study of the facts at his disposal deserves the attention of legal scholars. And, in terms of the historical record, too easy an acceptance of the idea that the Court's decision was founded on a carefully balanced appreciation of all the relevant facts would be a serious error.

\section{ACKNOWLEDGEMENTS}

I would like to thank the two anonymous referees for their helpful comments. Jeff Noakes carried out some of the research for this article, and Rodney Neufeld provided useful references on matters of international law. The English versions of Danish documents are by the Translation Bureau, Foreign Affairs and International Trade Canada.

\section{REFERENCES}

ANON. 1916a. Greenland and the Danish Islands. New York Times, 21 August.

. 1916b. Peary view as to U.S. "rights" in Greenland. Christian Science Monitor, 11 September.

— 1933. The legal status of Eastern Greenland. Geographical Journal 82(2): $151-156$.

BERLIN, K. 1932. Denmark's right to Greenland: A survey of the past and present status of Greenland, Iceland and the Faroe Islands in relation to Norway and Denmark. Translated by P.T. Federspiel. London: Oxford University Press/Copenhagen: Arnold Busck.

BULL, J. 1929. La question de la souveraineté sur le Groenland oriental. Revue de droit international et de législation comparée, 3e série, 10:572-605.

CLIPPERTON ISLAND CASE. 1932. Arbitral award on the subject of the difference relative to the sovereignty over Clipperton Island. American Journal of International Law 26(2):390-394.

DAVIS, C.H. 1876. Narrative of the North Polar Expedition, U.S. ship Polaris, Captain Charles Francis Hall commanding. Washington, D.C.: Government Printing Office.

ERITREA/YEMEN CASE. 1999. Award of 9 October 1998. International Law Reports 114:1-139.

FEDERSPIEL, P.T. 1932. The disputed sovereignty over East Greenland. International Affairs 11(6):783-811.

FREUCHEN, P. 1935. Arctic adventure: My life in the frozen North. New York: Farrar and Rinehart.

GAD, F. 1971. The history of Greenland, Vol. I: Earliest times to 1700. Translated by E. Dupont. Montreal: McGill-Queen's University Press.

- 1973. The history of Greenland, Vol. II: 1700-1782. Translated by G.C. Bowden. Montreal: McGill-Queen's University Press.

GILBERG, R. 1988. Inughuit, Knud Rasmussen, and Thule.Études/ Inuit/ Studies 12(1-2):45-55.

HERBERT, W. 1989. The noose of laurels: Robert E. Peary and the race to the North Pole. New York: Athenaeum.

ICJ (INTERNATIONAL COURT OF JUSTICE). 2001. Qatar v. Bahrain. Judgment of 16 March 2001. International Court of Justice, Reports of Judgments, Advisory Opinions and Orders, $40-118$.

2002. Indonesia/Malaysia. Judgment of 17 December 2002. International Court of Justice, Reports of Judgments, Advisory Opinions and Orders, 625-686.

LINDOW, H. 1929. Trade and administration of Greenland. In: Vahl, M., Amdrup, G.C., Bobé, L., and Jensen, A.S., eds. Greenland, Vol. III: The colonization of Greenland and its history until 1929. Copenhagen: C.A. Reitzel/London: Oxford University Press.

MALAURIE, J. 1982. The last kings of Thule. New York: Dutton. McKITTERICK, T.E.M. 1939. The validity of territorial and other claims in polar regions. Journal of Comparative Legislation and International Law, 3rd series, 21(1):89-97.

NYEBOE, I. 1935. Stationen Thule. Trent University Archives, Trevor Lloyd Papers, File 87-014-6-2. 
PCIJ (PERMANENT COURT OF INTERNATIONAL JUSTICE). 1933a. Series A/B (Collection of judgments, orders and advisory opinions), No. 53, Legal status of Eastern Greenland. Leyden: A.W. Sijothoff.

. 1933b. Series C (Pleadings, oral statements and documents), No. 62, Legal status of Eastern Greenland. Leyden: A.W. Sijothoff.

-1933c. Series C (Pleadings, oral statements and documents), No. 64, Legal status of Eastern Greenland. Leyden: A.W. Sijothoff.

. 1933d. Series C (Pleadings, oral statements and documents), No. 65, Legal status of Eastern Greenland. Leyden: A.W. Sijothoff.

PREUSS, L. 1932. The dispute between Denmark and Norway over the sovereignty of East Greenland. American Journal of International Law 26(3):469-487.

RASMUSSEN, G. 1927. L'accord dano-norvégien sur le Groenland oriental et son historique. Revue de droit international et de législation comparée, 3e série, 8:646-696.

— 1931. La souveraineté du Danemark sur le Groenland. Revue de droit international et de législation comparée, 3e série, 12:220-233.

RASMUSSEN, K. 1925. K. Rasmussen to O.D. Skelton, 5 May. Library and Archives Canada, RG 25, Vol. 1386, File 1324.

- 1926. Handelsstationen Thule. Trent University Archives, Trevor Lloyd Papers, File 87-014-6-2.

ROTHWELL, D. 1996. The polar regions and the development of international law. Cambridge: Cambridge University Press.

RUDA, J.M. 1992. The opinions of Judge Dionisio Anzilotti at the Permanent Court of International Justice. European Journal of International Law 3(1):100-122.

SAND, R. 1934. Nogle bemærkinger om Kap York Stationen Thule af overretasagfører Rudolf Sand stationens administrator. Trent University Archives, Trevor Lloyd Papers, File 87-014-6-2.

SHAW, M.N. 2003. International law, 5th ed. Cambridge and New York: Cambridge University Press.

SKEIE, J. 1932. Greenland: The dispute between Norway and Denmark. London and Toronto: Dent.
SMEDAL, G. 1931. The acquisition of sovereignty over polar areas. Oslo: Jacob Dybwad.

STAFFORD, M.P. 1974. Peary's ideas about US rights in Greenland. Draft article for Stefansson, V., ed. Encyclopedia Arctica (unpublished), Reel 27. Ann Arbor: University Microfilms International/Hanover, New Hampshire: Dartmouth College Library.

STEENSBY, H.P. 1909. The Polar Eskimos and the polar expeditions. Fortnightly Review, New Series 86(515):891-902.

STEFANSSON, V. 1974a. United States in relation to Greenland. Draft article for Stefansson, V., ed., Encyclopedia Arctica (unpublished), Reel 27. Ann Arbor: University Microfilms International/ Hanover, New Hampshire: Dartmouth College Library.

. 1974b. Greenland in international relations. Draft article for Stefansson, V., ed., Encyclopedia Arctica (unpublished), Reel 27. Ann Arbor: University Microfilms International/ Hanover, New Hampshire: Dartmouth College Library.

SVARLIEN, O. 1964. The Eastern Greenland case in historical perspective. Gainesville, Florida: University of Florida Press.

TANSILL, C.C. 1966. The purchase of the Danish West Indies. Gloucester, Massachusetts: Peter Smith.

TRIGGS, G. 1986. International law and Australian sovereignty in Antarctica. Sydney: Legal Books.

U.S. DEPARTMENT OF STATE. 1940. Foreign relations of the United States: The Lansing Papers, 1914-1920, Vol. II. Washington, D.C.: U.S. Government Printing Office.

- 1971. Treaties and other international agreements of the United States of America 1776-1949, Vol. 7: Denmark-France. Washington, D.C.: U.S. Government Printing Office.

VAUGHAN, R. 1991. Northwest Greenland: A history. Orono, Maine: University of Maine Press.

VON DER HEYDTE, F.A. 1935. Discovery, symbolic annexation and virtual effectiveness in international law. American Journal of International Law 29(3):448-471.

WALDOCK, C.H.M. 1948. Disputed sovereignty in the Falkland Islands Dependencies. British Yearbook of International Law 311-53. 